\title{
Landscape Characteristics Related to Use of Artificial Roosts by Northern Long-eared Bats in North-central West Virginia
}

\author{
Jesse L. De La Cruz ${ }^{1,2, *}$, Ryan L. Ward ${ }^{2}$, and Eric S. Schroder ${ }^{2}$
}

\begin{abstract}
In the eastern US, research is needed on the establishment and evaluation of conservation measures for forest-dwelling bats, in general, and for the newly listed Myotis septentrionalis (Northern Long-Eared Bat), in particular. Our objectives were to evaluate the overall use of 3 artificial roosting structures-rocket box, nursery box, and artificial bark-by bats and to relate this use to local landscape characteristics in north-central West Virginia. We monitored 306 structures during summer 2016 and detected use (i.e., presence of guano, visual identification, capture of bats) at $132(43 \%)$ roosts, of which $55(42 \%)$ were confirmed, through capture or visual identification, to contain Northern Long-eared Bats. Nursery boxes were used more than expected based on availability $(60 \%)$, but rocket boxes accounted for $40(73 \%)$ of the roosts confirmed to be occupied by Northern Long-eared Bats, with $70 \%$ being used by maternity colonies of this species. We utilized binomial generalized linear models and an information theoretic approach to examine use of artificial roosts by maternity colonies of Northern Long-eared Bats. Our best-supported model differentiating structures occupied by maternity colonies from those that housed individual bats showed relationships to elevation, slope, area solar radiation, and distance to streams and large $(>200$ ha) forests. Our study provides initial guidance for land and wildlife managers on implementing an effective conservation and management technique for bats within this region.
\end{abstract}

\section{Introduction}

Understanding relationships between a species and its habitat is critical for enacting effective plans for management and conservation (Morrison 2001). Nevertheless, knowledge of bat habitat and its role in their conservation and management is often lacking, especially in landscapes experiencing anthropogenic change (Coleman and Barclay 2012, Russo and Ancillotto 2015). Tree-clearing is known to remove habitat for forest-dwelling bats (Henderson et al. 2008), but the incidental removal of roost trees for human development, forest management, or energy development only recently has been shown to cause fragmentation of maternity colonies of forest-dwelling bats (Silvis et al. 2015); however, natural disturbances to forest ecosystems such as fire have been shown to create roosting habitat (Ford et al. 2016a). Disruptions of basic social units have the potential to impact the abundance and diversity of many forest-

\footnotetext{
${ }^{1}$ Conservation Management Institute at Virginia Polytechnic Institute and State University, 1900 Kraft Drive, Suite 105, Blacksburg, VA 24061. ${ }^{2}$ AllStar Ecology LLC, 1582 Meadowdale Road, Fairmont, WV 26554. 'Corresponding author - delacruz@vt.edu.
}

Manuscript Editor: Allen Kurta 
dependent bats (Hayes and Loeb 2007), including threatened and endangered species of high conservation concern.

Recent population declines of Myotis septentrionalis (Trouessart) (Northern Long-eared Bat) due to White Nose Syndrome (WNS) caused by the fungal pathogen Pseudogymnoascus destructans (Gargas, Trest, Christensen, Volk, and Blehert) have been extreme. As a result of this decline, the species was recently listed as threatened in the US (US Fish and Wildlife Service 2015) and endangered in Canada (Committee on the Status of Endangered Wildlife in Canada 2013). Northern Long-eared Bats generally appear dependent on contiguous, mature forest for both roosting and foraging (Silvis et al. 2016, USFWS 2015). In the central Appalachian Mountains and Ohio River Valley, both maternity colonies and solitary males rely on cavities in declining trees or snags for roosts (Johnson et al. 2009, Silvis et al. 2012). Some currently common practices in forest management, however, may not promote the roosting conditions required by this species, and it is unknown how long-term changes in habitat structure and forest composition may affect the distribution of the species (Owen et al. 2004; Silvis et al. 2012, 2016).

Artificial-roost construction is a potential conservation tool for many species of bats, although fewer than 10 publications have examined the role of imitation roosts in the conservation of North American species (Rueegger 2016). Little is known about the use of artificial structures by Northern Long-eared Bats, and available information is mostly anecdotal (Adams et al. 2015, Damm et al. 2015, Ritzi et al. 2005, Whitaker et al. 2006). In this study, we explored the use of more than 300 artificial roosts by Northern Long-eared Bats in north-central West Virginia during 2016. These roosts were installed as part of Habitat Conservation Plans (HCPs; USFWS 2016) that were implemented in coordination with the West Virginia Field Office of the USFWS (USFWS WV) as mitigating measures for potential impacts to endangered and threatened bats from forest-clearing activities. Our goals were to evaluate use of 3 types of artificial roosts and examine habitat characteristics associated with roosts used by Northern Long-eared Bats.

\section{Field-site Description}

We examined artificial roosts that were distributed across 98,900 ha of Doddridge, Tyler, and Ritchie counties, WV (Fig. 1), in the Western Hill subphysiographic province of the Appalachian Region (Stausbaugh and Core 1978). The Western Hill Section, adjacent to the Ohio River, is primarily composed of central hardwood forest (xeric), cove hardwoods (mesic), and floodplain communities (hydric) (Braun 1950). Topography of this region is characterized by moderate-tostrong relief (150-450 m elevation), with the northern counties, including those of the study area, being less rugged than their southern counterparts (Strausbaugh and Core 1978, Topalanchik 1989). The study area is $\sim 75 \%$ forested, experiences an average daily temperature of $22{ }^{\circ} \mathrm{C}$ from June through August, and receives 14-16.5 $\mathrm{cm}$ of precipitation during mid-summer (Topalanchik 1989). The region consists of a mix of corporate and non-industrial private forests, many of which are routinely subjected to harvest (Birch 1994, Joshi and Arano 2009). Over the past decade, the 
region has been a central area in the exploration and development of the Marcellus tight-shale gas reservoir (Hein 2012).

\section{Methods}

\section{Occurrence of bats}

Artificial roosting structures. As part of the HCPs, artificial roosts $(n=306)$ were installed from November 2015 to April 2016. Three artificial roosting types were used: rocket boxes $(n=203)$, nursery boxes $(n=53)$, and artificial bark $(n=$ 50) (Fig. 2). The number and type of artificial roosts were determined by project proponents and USFWS WV. Rocket boxes were tall, rectangular structures, with external dimensions of $1.2 \mathrm{~m}$ high $\mathrm{x} 0.3 \mathrm{~m}$ wide $\mathrm{x} 0.3 \mathrm{~m}$ deep and an internal volume (V) of $0.03 \mathrm{~m}^{3}$, excluding the post and slats. Rocket boxes possessed 2 vertical chambers in each of the 4 faces, offering 8 roosting chambers that mimicked tree cavities and provided a large volume of roosting space and thermal gradients (Burke 1999). Compared to rocket boxes, nursery boxes were smaller in both height and depth (0.8 $\mathrm{m}$ high $\times 0.4 \mathrm{~m}$ wide $\mathrm{x} 0.1 \mathrm{~m}$ deep; $\left.\mathrm{V}=0.01 \mathrm{~m}^{3}\right)$ and contained only 4 chambers, from front to back. However, the forward surface area of nursery boxes nearly equaled that of any 1 side of a rocket box, thus providing a larger proportional facade for solar heating with proper orientation, and the 4 successive chambers offered different thermal regimes (Kiser and Kiser 2004). Artificial bark is a rubberized substance that mimics the exfoliating bark of large snags (Gumbert et al.

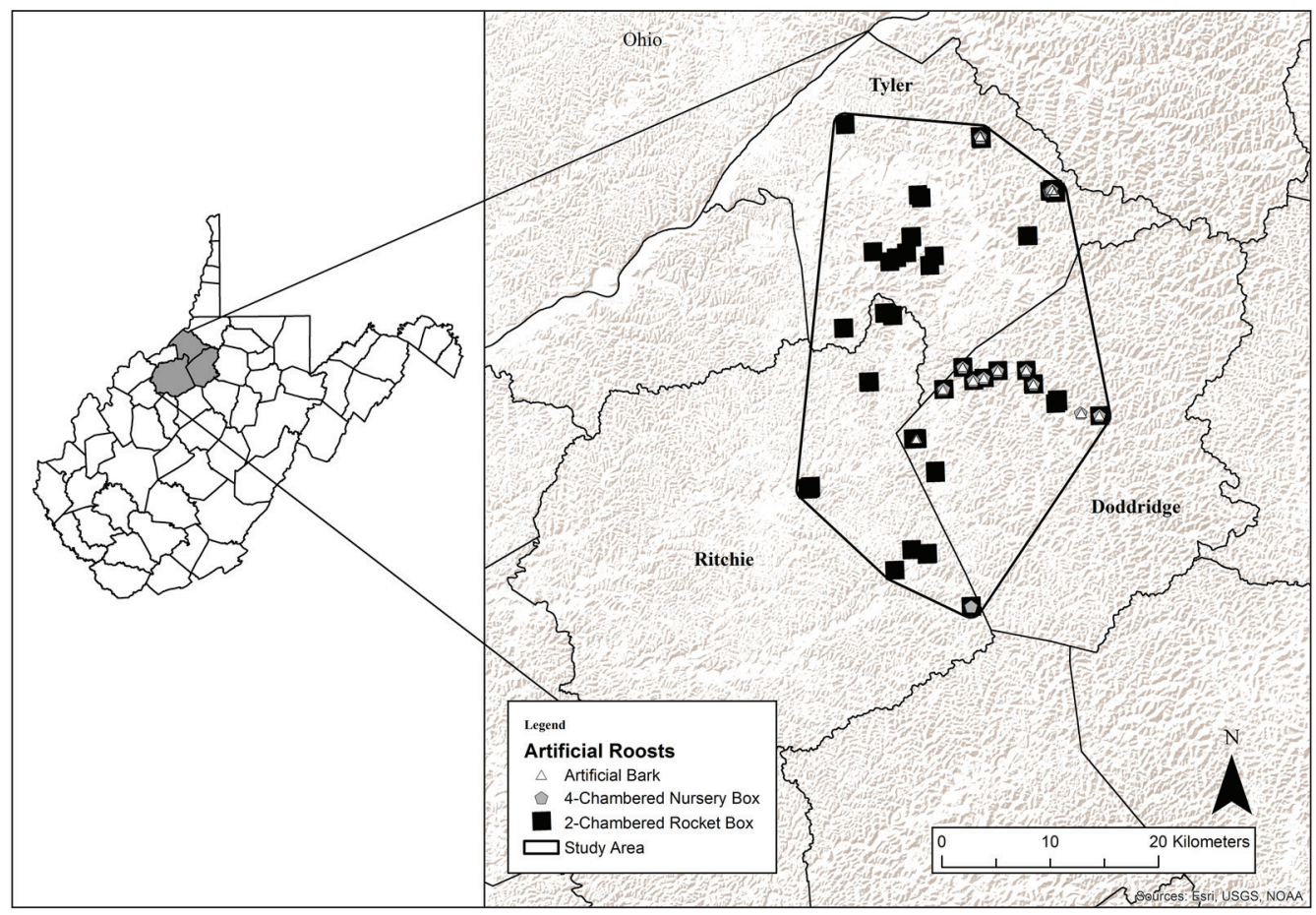

Figure 1. Approximate locations of artificial roosts in Doddridge, Ritchie, and Tyler counties, WV, 2016. 
2013). These roosts were built by attaching the artificial bark, lined with plastic netting to provide a textured climbing surface, to vertical wooden struts fastened at equal intervals around an unprocessed, cylindrical log $(1 \mathrm{~m}$ high $\mathrm{x} 0.25 \mathrm{~m}$ diameter $\mathrm{x} 0.02 \mathrm{~m}$ deep; $\mathrm{V}=0.02 \mathrm{~m}^{3}$ ). Each type of structure was attached to and mounted
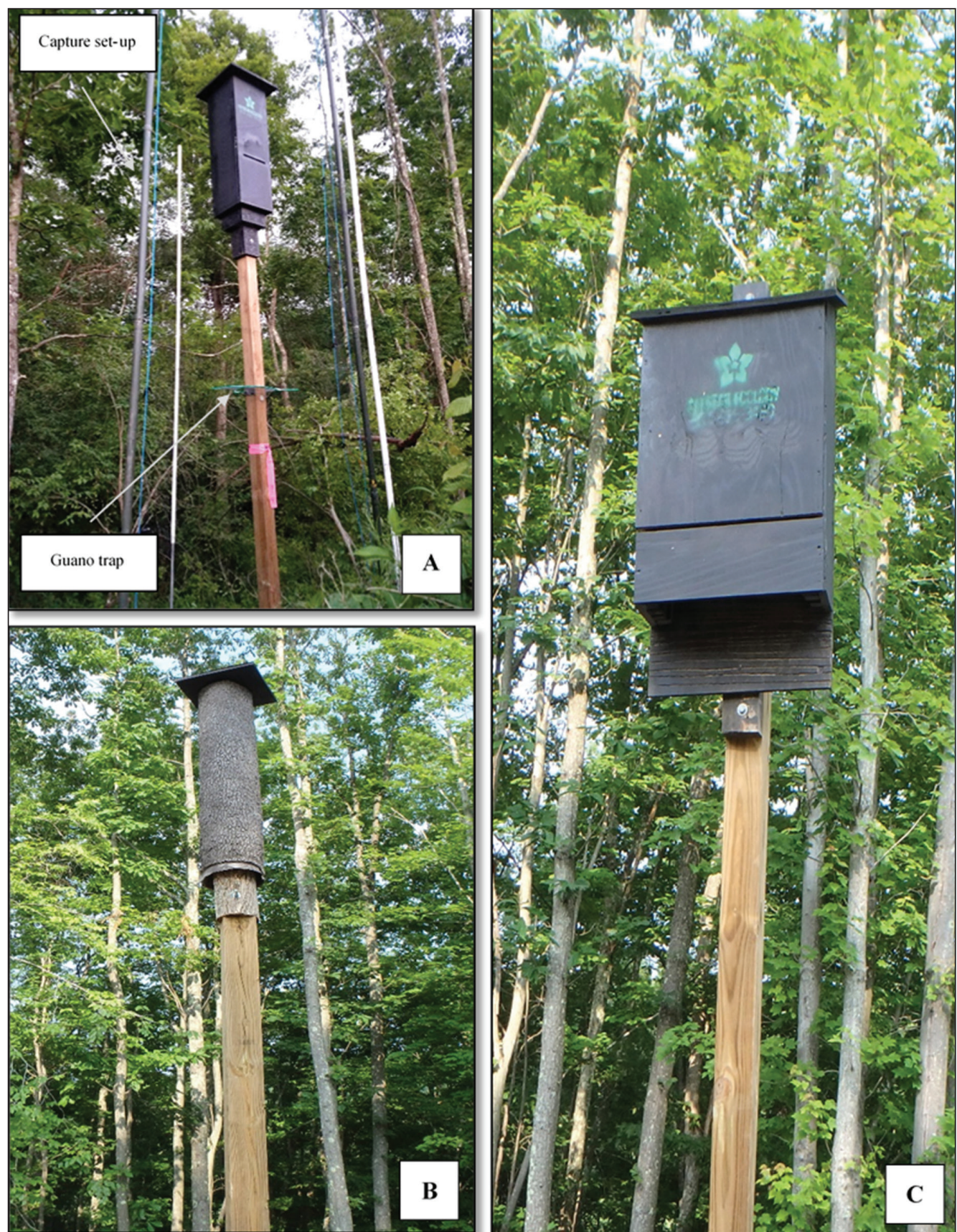

Figure 2. (A) rocket box with guano trap and emergence capture set-up, (B) artificial bark, and (C) nursery box in north-central WV, 2016. 
upright on a rectangular wooden post $(10 \mathrm{~cm} \mathrm{x} 10 \mathrm{~cm}$ for rocket and nursery boxes, and $15 \mathrm{~cm} \times 15 \mathrm{~cm}$ for artificial bark) so that the entrance for each roost was $4 \mathrm{~m}$ above the ground (Fig. 2).

Passive monitoring. We conducted passive monitoring at artificial roosts by visual examination of guano traps attached to each post (Gumbert et al. 2013). These traps $(38 \mathrm{~cm} \times 38 \mathrm{~cm})$ were constructed of rigid $7-\mathrm{mm}$-gauge wire mesh, lined with fine window-screen and attached to the post about $1.5 \mathrm{~m}$ from the ground (Fig. 2A). Exposed edges of wire were coated with silicone (Dip Seal Plastics, Inc., Rockford, IL) to increase longevity of the trap and ensure no injury to bats. Traps were placed in early June 2016 and left through late August 2016. Roosts were actively (manually) monitored only 1-2 times per season; thus, guano traps provided a longer sampling period of 2.5 months, during which we inferred use by presence of guano. Precipitation causes the guano to disintegrate over time; consequently, our occupancy estimates may be overly conservative, because roosts used only sparingly or by few bats may have been undercounted.

Active monitoring and capture. We actively monitored artificial roosts over 1-2 visits from 1 June to 15 August 2016. We visually examined all structures diurnally using a thermal camera (Compact, Seek Thermal, Inc., Santa Barbra, CA) and a small, red-filtered light (McNamara, Rochester, NY). Our use of the thermal camera allowed a noninvasive examination of the structure, whereas the red-filtered light allowed a direct visual examination that minimized disturbance to bats but ensured that single bats, which emit a small thermal signature, were not missed during monitoring. To provide a more complete census and to prioritize capture efforts, we identified observed bats to species using non-handling identification methods (Christenson 2011).

We only attempted bat captures at some roosts, with preference given in this order: roosts occupied by multiple bats, bats identified as likely Northern Longeared Bats, and bats identified as likely Eptesicus fuscus Palisot de Beauvois (Big Brown Bat). We captured bats during emergence using mist nets $(2.6 \mathrm{~m}$ high $\mathrm{x} 6 \mathrm{~m}$ wide with a $38-\mathrm{mm}$ mesh; Avinet, Inc., Portland, ME) that encircled the roosts via a 4-pole system that enabled nets to be raised evenly to a height of about $3.5 \mathrm{~m}$ (Fig. 2A). We recorded data on species, site, sex, reproductive condition, and age for each captured bat. We defined maternity colonies of captured bats as a group of bats consisting of $>1$ pregnant or lactating adult or any assemblage of reproductive females that also included juvenile bats. If capture was impossible, we described roost occupancy based on visual identification to species, timing as related to bat reproduction (e.g., colony formation, parturition), and a qualitative assessment of group size (i.e., few or many bats visible, small or large amount of guano present). We differentiated captured adult and juvenile bats by the degree of ossification of the epiphyseal cartilage in the transilluminated metacarpal-phalangeal joints (Kunz and Anthony 1982). We banded (2.9 mm; Porzana Limited, East Sussex, UK) all adult Northern Long-eared Bats to allow individual identification.

\section{Habitat}

To assess the surrounding habitat, we recorded distance to streams and forest fragments and measures of aspect, elevation, slope, and solar radiation for each 
artificial structure. We defined distance to streams as the Euclidean distance from each artificial roost to the nearest stream in the National Hydrography Dataset (1:100000 scale; US Geological Survey 2002) as measured with the Joins and Relates tools of ArcGIS (version 10.2.1; ESRI, Inc., Redlands, CA). Similarly, we measured distance from each artificial roost to surrounding forest fragments using ArcGIS. We derived elevation from digital elevation-models (3-m resolution; US Geological Survey and West Virginia State Addressing and Mapping Board 2003) and also used the Spatial Analyst extension of ArcGIS to determine slope, aspect, and area solar radiation (ASR) from those models. The ASR, in units of watt hours per square meter $\left(\mathrm{W}-\mathrm{h} / \mathrm{m}^{2}\right)$, accounts for local atmospheric effects, latitude and elevation, slope and aspect, seasonal angle of the sun, and shadows of surrounding topography (Tovar-Pescador et al. 2006).

We used the Image Classification extension within Spatial Analyst to extract basic land-cover classes from aerial imagery provided by the 2016 National Agriculture Imagery Program (NAIP; US Department of Agriculture 2016). We utilized a supervised, maximum-likelihood classification to create 3 basic cover-classes: forest, open non-forested, and developed (Dewan and Yamaguchi 2009). We used the Raster Calculator in ArcGIS with existing data to add 4 other classes: open water, emergent wetlands, woody wetlands, and census roads (Strager 2012). Based on these combined data, we examined forest fragmentation (i.e., forest or non-forest) using the Landscape Fragmentation Tool of ArcGIS (Vogt et al. 2007) and classified forest fragmentation into 4 primary categories: patch (forest fragments degraded by edge effect), edge (forest periphery degraded by edge effect), perforated (interior forest edge), and core forest (forest area not degraded by edge effect). We further classified core forest as small ( $<100 \mathrm{ha})$, medium (100-200 ha), or large ( $>200 \mathrm{ha})$.

We used the Geospatial Modelling Environment to examine locations of artificial roosts relative to landscape variables (Beyer 2010). We converted raster values to point locations using the "isectpntrst" command, which enabled us to export data as a viewable text file.

\section{Statistical analysis}

To compare landscape characteristics between roosts of maternity colonies and individual Northern Long-eared Bats, we fit global, binomial, generalized linear models that incorporated all variables, ranked by Akaike's information criterion (AIC), using a stepwise procedure on bootstrap samples $(n=1000)$ of the data. Rather than compare a suite of intuitive models, this method investigates variability of model selection via data simulation-model refit using simulated data and the application of the stepAIC algorithm to the refitted model(s) to find the bestsupported model (Dunn et al. 2010, Stepper et al. 2015). Artificial roosts were counted as single locations and use was pooled across visits; thus, we assumed independence of structures. To avoid problems of circularity when analyzing aspect, we used sine and cosine transformations of the data (Odom et al. 2001). We assessed significance of individual parameters within the best-supported model by using Wald's chi-square test, and overall fit of the model by using the log- 
likelihood-ratio test against a null model as well as the area under the receiver operating characteristic curve (AUC). We employed a chi-square goodness-of-fit test to determine if overall use of roosts and use by maternity colonies of Northern Long-eared Bats were uniformly distributed by type of artificial structure. We conducted all statistical analyses in program $\mathrm{R}$ (version 3.3.3; R Core Team 2015) and based our approach upon methods and code described in McDonald (2014), Mangiafico (2015), and package bootStepAIC (Dimitris Rizopoulos 2015). All tests were performed using $\alpha \leq 0.05$ to determine significance.

\section{Results}

We detected use (i.e., presence of guano, visual identification, or capture of bats) at 132 artificial roosts (43\% of all available roosts) including 84 rocket boxes ( $41 \%$ of rocket boxes), 32 nursery boxes ( $60 \%$ of nursery boxes), and 16 artificial-bark roosts (32\% of artificial-bark roosts). Presence of guano was the sole, non-species-specific indicator of use for $75(57 \%)$ of the 132 roosts, visual identification occurred at $28(21 \%)$ occupied structures, and we captured bats at $29(22 \%)$ roosts. Compared to rocket boxes and artificial bark, nursery boxes were used more than expected based on availability $\left(\chi^{2}=9.2, \mathrm{df}=2, P=0.01\right)$. Overall, we identified only 2 bat species using artificial structures-we detected Northern Long-eared Bats at 55 roosts and Big Brown Bats at 2 roosts. We verified presence of Big Brown Bats through capture at structures $(n=2,100 \%)$, whereas we confirmed presence of Northern Long-eared Bats by both capture $(n=27 ; 49 \%)$ and visual identification $(n=28 ; 51 \%)$. We caught 123 unique bats, of which 119 (97\%) were Northern Long-eared Bats and 4 (3\%) were Big Brown Bats; $78 \%$ of captured Northern Long-eared bats and all Big Brown Bats were from rocket boxes (Table 1).

Of the 55 structures occupied by Northern Long-eared Bats, $45(82 \%)$ roosts contained only 1-2 individuals, with 18 (67\%) of the 27 roosts at which this species was caught containing only non-reproductive individuals (Table 1). We confirmed via mist-netting that 9 structures housed maternity colonies of Northern Long-eared Bats, which resulted in the capture of 101 bats (Table 1); one maternity colony was inferred visually via species identification, a monitoring date (24 June 2016) that coincided with the maternity period (Silvis et al. 2014), and qualitative assessment of colony size. Rocket boxes accounted for 7 of 10 structures used by maternity colonies and were the only structures to house-as individual roosts were monitored sequentially and progressively throughout the summer - pregnant Northern Long-eared Bats and then both non-volant and volant pups. However, maternity colonies occupied no type of structure more than expected based on availability $\left(\chi^{2}=0.16, \mathrm{df}=2, P=0.92\right)$.

Given the prevalence of Northern Long-eared Bats and their conservation status, we restricted analysis of landscape variables to this species. Our best-supported model differentiating landscape characteristics at the 10 roosts occupied by maternity colonies from the 45 structures used by other Northern Long-eared Bats 
contained elevation, slope, ASR, streams, and large-core forest (Table 2). Under this model, probability of maternity occupancy of an artificial roost increased with rising slope, elevation, and increasing distance from streams and large forests but decreased with increasing ASR. This model provided a better fit than the null model (log-likelihood $=-26.08, P=0.01)$ and displayed moderate predictive power (AUC $=0.84)$ (Table 2).

Table 1. Summary of use of 3 types of artificial roosts by bats, following passive and active monitoring in Doddridge, Ritchie, and Tyler counties, WV, 2016.

\begin{tabular}{|c|c|c|c|c|c|}
\hline \multirow[b]{2}{*}{$\begin{array}{l}\text { Monitoring } \\
\text { technique }\end{array}$} & \multirow[b]{2}{*}{ Statistic } & \multicolumn{4}{|c|}{ Artificial roosts } \\
\hline & & $\begin{array}{c}\text { Artificial } \\
\text { bark }\end{array}$ & $\begin{array}{l}\text { Nursery } \\
\text { box }\end{array}$ & $\begin{array}{c}\text { Rocket } \\
\text { box }\end{array}$ & Total \\
\hline & $n$ & 50 & 53 & 203 & 306 \\
\hline Passive monitoring & Identified roosts & 15 & 18 & 42 & 75 \\
\hline \multirow[t]{4}{*}{ Visual observations } & $\begin{array}{l}\text { Roosts used by Big Brown Bat maternity } \\
\text { colonies }\end{array}$ & 0 & 0 & 0 & 0 \\
\hline & Roosts used by individual(s) Big Brown Bats & 0 & 0 & 0 & 0 \\
\hline & $\begin{array}{l}\text { Roosts used by Northern Long-eared Bat } \\
\text { maternity colonies }\end{array}$ & 1 & 0 & 0 & 1 \\
\hline & $\begin{array}{l}\text { Roosts used by individual(s) Northern } \\
\text { Long-eared Bats }\end{array}$ & 0 & 7 & 20 & 27 \\
\hline \multirow[t]{8}{*}{ Active capture } & $\begin{array}{l}\text { Roosts of captured Big Brown maternity } \\
\text { colonies }\end{array}$ & 0 & 0 & 1 & 1 \\
\hline & Roosts used by individual(s) Big Brown Bats & 0 & 0 & 1 & 1 \\
\hline & $\begin{array}{l}\text { Roosts used by Northern Long-eared Bat } \\
\text { maternity colonies }\end{array}$ & 0 & 2 & 7 & 9 \\
\hline & $\begin{array}{l}\text { Roosts used by individual(s) Northern } \\
\text { Long-eared Bats }\end{array}$ & 0 & 5 & 13 & 18 \\
\hline & Total roosts used & 16 & 32 & 84 & 132 \\
\hline & Number of captured Big Brown Bats & 0 & 0 & 4 & 4 \\
\hline & Number of captured Northern Long-eared Bats & 0 & 26 & 93 & 119 \\
\hline & Total bats captured & 0 & 26 & 97 & 123 \\
\hline
\end{tabular}

Table 2. Parameters and summary of best-supported model describing characteristics of roosts used by maternity colonies roost $(n=10)$ of Northern Long-eared Bats in Doddridge, Ritchie, and Tyler counties, WV, in 2016.

\begin{tabular}{lccc} 
Variable & DF & Wald $\chi^{2}$ & $P>\chi^{2}$ \\
\hline Elevation & 1 & 4.34 & 0.04 \\
Slope & 1 & 3.60 & 0.06 \\
ASR & 1 & 4.25 & 0.04 \\
Streams & 1 & 4.46 & 0.03 \\
Large core forest & 1 & 4.04 & 0.04 \\
Best-supported model & Log-likelihood & $P>\chi^{2}$ & AUC \\
\hline Elevation + slope + ASR + streams + large core & -26.08 & 0.01 & 0.84 \\
\hline
\end{tabular}




\section{Discussion}

Few data regarding use of artificial roosts as a conservation measure in North America are available (Rueegger 2016), and use of such sites by individuals or maternity colonies of Northern Long-eared Bats has rarely been documented (Burke 1999, Fagan et al. 2018, Silvis et al. 2016, Whitaker et al. 2004). Our results show that overall use of artificial roosts by bats of any species was high (43\%) and occurred quickly (i.e., during the first maternity season following installation). Approximately $18 \%$ of structures were occupied by Northern Long-eared Bats, and at least 10 artificial roosts were occupied by maternity colonies of this species, suggesting that placement of artificial structures is a potentially beneficial practice. Rocket boxes accounted for most roosts that housed reproductive (pregnant and lactating adults) and juvenile (volant and non-volant pups) Northern Long-eared Bats. Nursery boxes were selected more than expected based on availability but were typically used by few individuals.

Due to the morphological similarities of the genus Myotis, researchers must be aware of the potential for species misclassification. Difficulties in accurate identification may be further compounded when observing bats from a distance and in poor lighting. However, visual identifications and counts have long been viable methods for censusing bats (Hoying and Kunz 1998, Kunz 2003). We attempted to mitigate for visual-misidentification bias by following available and applicable keys (Christenson 2011), and relating unique visual identifiers (e.g., long ears, pointed tragus) with those of captured bats. Furthermore, illuminating roosting chambers with a bright light enabled visual identifiers to be seen more clearly; use of a red-filtered light was only an attempt to reduce animal stress. Moreover, understanding the reproductive biology of Northern Long-eared Bats, of colony formation, parturition, and juvenile volancy (Silvis et al. 2014), enabled logical inferences to be made regarding the visual classification of a single maternity colony. Our visual identifications are also supported by the fact that $97 \%$ of bats identified after capture at artificial roosts were Northern Long-eared Bats. Finally, based on data from the West Virginia Division of Natural Resources (WVDNR), only 6 Myotis lucifugus (Le Conte) (Little Brown Bat) and 4 Myotis sodalis (Miller and G.M. Allen) (Indiana Bat) were captured statewide during summer 2016 (C.W. Stihler, WVDNR, South Charleston, WV; pers. comm.). These statewide data suggest a low abundance of species morphologically similar to the Northern Long-eared bat, and further support our visual identifications of roosting bats.

Similar to previous research on natural roosts, our results showed that maternity colonies of Northern Long-eared Bats were associated with upper elevations (Brack et al. 2002; Johnson et al. 2009, 2012; Jung et al. 2004; Lacki and Schweirjohann 2001; Silvis et al. 2012). Silvis et al. (2012) postulated that these upper slopes, particularly those associated with early-successional tree species (Lorimer and White 2003), were disturbed more frequently (e.g., by fire or windthrow) and to a higher degree than other landforms, thus providing increased availability of natural roosts for Northern Long-eared Bats (Ford et al. 2016a, b). In addition, our analysis found that structures selected by maternity colonies were located farther from streams 
than were roosts used by individuals. This result is similar to previous research on roosting (Johnson et al. 2009) and foraging (Ford et al. 2005) by Northern Longeared Bats in West Virginia. State-wide recommendations from the West Virginia Division of Forestry exclude riparian areas from logging operations (Kochenderfer et al. 2005), which results in less disturbance in those portions of the forest. It may be that artificial roosts used by Northern Long-eared Bats were placed in forested areas that contained or previously contained roosting sites that resulted from natural disturbances or anthropomorphic impacts, which are typically suppressed in riparian areas.

Although high solar radiation is widely assumed to benefit maternity colonies of temperate insectivorous bats, few studies have examined the effect of solar radiation at the local-landscape level on the use of roosts (Ford et al. 2016a, b; Johnson et al. 2009; Silvis et al. 2012, 2016). By measuring a leaf-area index, Silvis et al. (2012) found that roosts of Northern Long-eared Bats were located in dense, shaded forests, though in a geographic region with a higher summer temperature than our study site. Measures of canopy closure have typically indicated that regionally, Northern Long-eared Bats use suppressed and shaded trees that receive little direct solar radiation (Johnson et al. 2012, Lacki and Schweirjohann 2001, Menzel et al. 2002, Silvis et al. 2012). Patriquin et al. (2017) reported that roost switching by Northern Long-eared Bats was linked to ambient conditions whereby solar exposure was more important in the northern or montane portions of the species' distribution than in the southern portion. Specifically, their research suggested use of shorter, decayed trees on warm days and use of less decayed roosts of smaller diameter on windy, rainy days. Our analysis showed that use of artificial roosts decreased as ASR increased between maternity colonies and individual Northern Long-eared Bats. Moreover, use of artificial structures by maternity colonies did not appear affected by proximity to forest gaps, a feature shown to improve the suitability of natural roosts of the Northern Long-eared Bat (Johnson et al. 2009).

Northern Long-eared Bats have long been described as requiring large areas of contiguous forest for both roosting and foraging (Broders et al. 2006, Carter and Feldhamer 2005, Henderson and Broders 2008, Lacki and Schweirjohann 2001, Perry and Thill 2007, Sasse and Pekins 1996). Similar to the findings of Owen et al. (2003), our results somewhat depart from this generality and indicate that artificial roosts were more likely to be used by colonies of Northern Long-eared Bats as distance from areas of large ( $>200 \mathrm{ha}$ ) forests increased. It may be that artificial roosts are selected less often when they are near large ( $>200 \mathrm{ha}$ ) forests due to a more diverse selection and greater availability of natural roost-trees (Callahan et al. 1997). Our analysis showed no relationship between distance to forest patch (i.e., forested areas degraded by edge effect) and use of roosts by maternity colonies, suggesting that there may be a threshold for intolerance of forest fragmentation by Northern Long-eared Bats, though it was not detected in our results. Distance between capture site (foraging area) and roosting location for Northern Long-eared Bats averages $375 \mathrm{~m}$ (Johnson et al. 2009, Silvis et al. 2012), but the maximum distance 
reported in the literature is $2.6 \mathrm{~km}$ (Badin 2014, Johnson et al. 2009). These results show the need for the interspersion of heterogeneous roosting and flyway habitat, and that isolated forest patches and large areas ( $>200 \mathrm{ha})$ of forest may lack roosts or diverse foraging areas and movement corridors necessary as habitat for Northern Long-eared Bats.

Our findings provide a regional assessment of artificial roosts as a conservation measure for bats and may aid in the identification of areas suitable for the installation of artificial roosts in north-central West Virginia. Use of artificial roosts is influenced by large-scale characteristics of the landscape, and placement of artificial structures should therefore be dictated by consideration of these environmental and physical features of the landscape. Our results indicate that managers, particularly on the Appalachian Plateau, should install artificial roosts for maternity colonies of Northern Long-eared Bats at upper elevations, of moderate-to-high slope, that are exposed to moderate solar radiation, and not in close proximity to streams or large forests ( $>200 \mathrm{ha})$. Furthermore, the high overall occupancy of nursery boxes and use of rocket boxes by multiple maternity colonies indicate that both styles should be placed in concert, to provide diverse roosting conditions for bats at all life-stages and reproductive conditions. Future research should investigate various assemblages of nursery and rocket boxes, with the aim of improving the potential use of this conservation measure as a replacement for natural roosts.

\section{Acknowledgments}

We thank N.W. Lafleur, S.T. Kline, M.R. Evans, and E.M. Weisent for providing technical field assistance; W.E. Veselka, T.J. Burhans, and V.C. Reaves for managerial contributions; A.L. Runner and W.M. Ford for editorial contributions; and AllStar Ecology LLC and Conservation Management Institute at Virginia Polytechnic and State University for support of this project.

\section{Literature Cited}

Adams, J., P. Roby, P. Sewell, J. Schwierjohann, M. Gumbert, and M. Brandenburg. 2015. Success of Brandenbark, an artificial-roost structure designed for use by Indiana Bats (Myotis sodalis). Journal of the American Society for Mining and Reclamation 4:1-15.

Badin, H.A. 2014. Habitat selection and roosting ranges of Northern Long-eared Bats (Myotis septentrionalis) in an experimental hardwood forest system. M.Sc. Thesis. Ball State University, Muncie, IN. 90 pp.

Beyer, H. 2010. Geospatial modelling environment. Available online at http://www. spatialecology.com/gme/. Accessed 8 February 2018.

Birch, T.W. 1994. Private forest-land owners of the United States, 1994. Resource Bulletin NE-134:1-183. US Department of Agriculture, Forest Service, Northeastern Forest Experimental Station, Newtown Square, PA.

Brack, V., Jr., C.W. Stihler, R.J. Reynolds, C.M. Butchkoski, and C.S. Hobson. 2002. Effect of climate and elevation on distribution and abundance in the Mideastern United States. Pp. 21-28, In A. Kurta and J. Kennedy (Eds.). The Indiana Bat: Biology and Management of an Endangered Species. Bat Conservation International, Austin, TX. 253 pp.

Braun, E.L. 1950. Deciduous forests of eastern North America. Blakiston Company, Philadelphia, PA. 596 pp. 
Broders, H.G., G.J. Forbes, S. Woodley, and I.D. Thompson. 2006. Range extent and stand selection for roosting and foraging in forest-dwelling Northern Long-eared Bats and Little Brown Bats in the Greater Fundy ecosystem, New Brunswick. Journal of Wildlife Management 70:1174-1184.

Burke H.S., Jr. 1999. Maternity-colony formation in Myotis septentrionalis using artificial roosts: The rocket box, a habitat enhancement for woodland bats? Bat Research News 40:77-78.

Callahan, E.V., R.D. Drobney, and R.L. Clawson. 1997. Selection of summer-roosting sites by Indiana Bats (Myotis sodalis) in Missouri. Journal of Mammalogy 78:818-825.

Carter, T.C., and G.A. Feldhamer. 2005. Roost-tree use by maternity colonies of Indiana Bats and Northern Long-eared Bats in southern Illinois. Forest Ecology and Management 219:259-268.

Christenson, K. 2011. Annotated key to the hibernating bats of the Northeast (using nonhandling methods of identification). Pp. 18-19, In M.J. Baker, J. Kennedy, J. Tyburec, and J. Chenger (Eds.). Bat Conservation and Management Workshop: Carter Cave State Park, KY. Bat Conservation International, Austin, TX. 211 pp.

Coleman, J.L., and R.M.R. Barclay. 2012. Urbanization and the abundance and diversity of prairie bats. Urban Ecosystems 87-102.

Committee on the Status of Endangered Wildlife in Canada. 2013. COSEWIC assessment and status report on the Little Brown Myotis (Myotis lucifugus), Northern Myotis (Myotis septentrionalis), Tri-colored Bat (Perimyotis subflavus) in Canada. Ottawa, ON, Canada. 93 pp.

Damm, J.P., D.W. Sparks, and J.O. Whitaker Jr. 2015. Bat-species diversity at an urbanrural interface: Dominance by one species in an urban area. Urban Naturalist 8:1-13.

Dewan, A.M., and Y. Yamaguchi. 2009. Using remote sensing and GIS to detect and monitor land use and land-cover change in Dhaka Metropolitan of Bangladesh during 1960-2005. Environmental Monitoring and Assessment 150:237-249.

Dimitris Rizopoulos, A. 2015. Package "bootStepAIC". Available online at https://cran.rproject.org/web/packages/bootStepAIC/bootStepAIC.pdf. Accessed 8 February 2018.

Dunn, D.C., K. Stewart, R.H. Bjorkland, M. Haughton, S. Singh-Renton, R. Lewison, L. Thorne, and P.N. Halpin. 2010. A regional analysis of coastal- and domestic-fishing effort in the wider Caribbean. Fisheries Research 102:60-68.

Fagan, K.E., E.V. Willcox, L.T. Tran, R.F. Bernard, and W.H. Stiver. 2018. Roost selection by bats in buildings, Great Smoky Mountains National Park. Journal of Wildlife Management 82:424-434.

Ford, W.M., M.A. Menzel, J.L. Rodrigue, J.M. Menzel, and J.B. Johnson. 2005. Relating bat-species presence to simple habitat-measures in a central Appalachian forest. Biological Conservation 126:528-539.

Ford, W.M., A. Silvis, J.B. Johnson, J.W. Edwards, and M.S. Karp. 2016a. Northern Longeared Bat day-roosting and prescribed fire in the central Appalachians, USA. Fire Ecology 12:13-27.

Ford, W.M., A. Silvis, J.L. Rodrigue, A.B. Kniowski, and J.B. Johnson. 2016b. Deriving habitat models for Northern Long-eared Bats (Myotis septentrionalis) from historical detection data: A case study using the Fernow Experimental Forest. Journal of Fish and Wildlife Management 7:86-98.

Gumbert, M., P. Sewell, J. Adams, P. Roby, J. Schwierjohann, and M. Brandenburg. 2013. Brandenbark $^{\circledR}$ : Artificial bark designed for roost use by Indiana Bats (Myotis sodalis). Proceedings of the International Conference on Ecology and Transportation. Scottsdale, AZ. Center for Transportation and the Environment, North Carolina State University, Raleigh, NC. 
Hayes, J.P., and S.C. Loeb. 2007. The influences of forest management on bats in North America. Pp. 207-235, In M.J. Lacki, J.P. Hayes, and A. Kurta (Eds.). Bats in Forests: Conservation and Management. Johns Hopkins University Press, Baltimore, MD. $368 \mathrm{pp}$.

Hein, C.D. 2012. Potential impacts of shale-gas development on bat populations in the northeastern United States. Delaware Riverkeeper Network, Bristol, PA. 33 pp. Available online at https://goo.gl/3hygJz. Accessed 30 July 2018.

Henderson, L.E., and H.G. Broders. 2008. Movements and resource selection of the Northern Long-eared Myotis (Myotis septentrionalis) in a forest-agriculture landscape. Journal of Mammalogy 89:952-963.

Henderson, L.E., L.J. Farrow, and H.G. Broders. 2008. Intra-specific effects of forest loss on the distribution of the forest-dependent Northern Long-eared Bat (Myotis septentrionalis). Biological Conservation 141:1819-1828.

Hoying, K.M., and T.H. Kunz. 1998. Variation in size at birth and post-natal growth in the insectivorous bat Pipistrellus subflavus (Chiroptera: Vespertilionidae). Journal of Zoology 245:15-27.

Johnson, J.B., J.W. Edwards, W.M. Ford, and J.E. Gates. 2009. Roost-tree selection by Northern Myotis (Myotis septentrionalis) maternity colonies following prescribed fire in a central Appalachian Mountains hardwood forest. Forest Ecology and Management 258:233-242.

Johnson, J.B., W.M. Ford, and J.W. Edwards. 2012. Roost networks of Northern Myotis (Myotis septentrionalis) in a managed landscape. Forest Ecology and Management 266:223-231.

Joshi, S., and K.G. Arano. 2009. Determinants of private forest-management decisions: A study on West Virginia NIPF landowners. Forest Policy and Economics 11:118-125.

Jung, T.S., I.D. Thompson, and R.D. Titman. 2004. Roost-site selection by forest-dwelling male Myotis in central Ontario, Canada. Forest Ecology and Management 202:325-335.

Kiser, M., and S. Kiser. 2004. A decade of bat-house discovery. The Bat House Researcher 12:1-12.

Kochenderfer, J., A. Gale, J. Scronce, D. Dean, D. McGill, M. Facemyer, J. Newland, and C.R. Dye. 2005. West Virginia silvicultural best management practices for controlling soil erosion and sedimentation from logging operations. West Virginia Division of Forestry, Charleston, WV. 31 pp.

Kunz, T.H. 2003. Censusing bats: Challenges, solutions, and sampling biases. Pp. 9-20, In T.J. O'Shea and M.A. Bogan (Eds.). Monitoring Trends in Bat Populations of the United States and Territories: Problems and Prospects. US Geological Survey, Springfield, VA. $274 \mathrm{pp}$.

Kunz, T.H., and E.L.P. Anthony. 1982. Age estimation and post-natal growth in the bat Myotis lucifugus. Journal of Mammalogy 63:23-32.

Lacki, M.J., and J. Schweirjohann. 2001. Day-roost characteristics of Northern Bats in a mixed mesophytic forest. Journal of Wildlife Management 65:482-488.

Lorimer, C.G., and A.S. White. 2003. Scale and frequency of natural disturbances in the northeastern US: Implications for early-successional forest habitats and regional agedistributions. Forest Ecology and Management 185:41-64.

Mangiafico, S.S. 2015. An R companion for the Handbook of Biological Statistics. 1.2.1. Rutgers Cooperative Extension, New Brunswick, NJ. 278 pp.

McDonald, J.H. 2014. Handbook of Biological Statistics, $3^{\text {rd }}$ Edition. Sparky House Publishing, Baltimore, MD. 299 pp. 
Menzel, M.A., S.F. Owen, W.M. Ford, J.W. Edwards, P.B. Wood, B.R. Chapman, and K.V Miller. 2002. Roost-tree selection by Northern Long-eared Bat (Myotis septentrionalis) maternity colonies in an industrial forest of the central Appalachian Mountains. Forest Ecology and Management 155:107-114.

Morrison, M.L. 2001. Introduction: Concepts of wildlife and wildlife habitat for ecological restoration. Restoration Ecology 9:251-252.

Odom, R.H., W.M. Ford, J.W. Edwards, C.W. Stihler, and J.M. Menzel. 2001. Developing a habitat model for the endangered Virginia Northern Flying Squirrel (Glaucomys sabrinus fuscus) in the Allegheny Mountains of West Virginia. Biological Conservation 99:245-252.

Owen, S.F., M.A. Menzel, W.M. Ford, and B.R. Chapman. 2003. Home-range size and habitat used by the Northern Myotis (Myotis septentrionalis). American Midland Naturalist 150:352-359.

Owen, S.F., M.A. Menzel, J.W. Edwards, W.M. Ford, J.M. Menzel, B.R. Chapman, P.B. Wood, and K.V. Miller. 2004. Bat activity in harvested and intact forest stands in the Allegheny Mountains. Northern Journal of Applied Forestry 21:154-159.

Patriquin, K.J., M.L. Leonard, H.G. Broders, W.M. Ford, E.R. Britzke, and A. Silvis. 2017. Weather as a proximate explanation for fission-fusion dynamics in female Northern Long-eared Bats. Animal Behaviour 123:355-357.

Perry, R.W., and R.E. Thill. 2007. Roost selection by male and female Northern Long-eared Bats in a pine-dominated landscape. Forest Ecology and Management 247:220-226.

R Core Team. 2015. R: A Language and Environment for Statistical Computing. R Foundation for Statistical Computing, Vienna, Austria. Available online at http://www.rproject.org/. Accessed 8 February 2018.

Ritzi, C.M., B.L. Everson, and J.O. Whitaker Jr. 2005. Use of bat boxes by a maternity colony of Indiana Myotis (Myotis sodalis). Northeastern Naturalist 12:217-220.

Rueegger, N. 2016. Bat boxes: A review of their use and application, past, present, and future. Acta Chiropterologica 18:279-299.

Russo, D., and L. Ancillotto. 2015. Sensitivity of bats to urbanization: A review. Mammalian Biology 80:205-212.

Sasse, D.B., and P.J. Pekins. 1996. Summer-roosting ecology of Northern Long-eared Bats (Myotis septentrionalis) in the White Mountain National Forest. Pp. 91-101, In R.M.R. Barclay and R.M. Bringham (Eds.). Bats and Forests Symposium, 19-21 October 1995. Victoria, BC, Canada. 302 pp.

Silvis, A., W.M. Ford, E.R. Britzke, N.R. Beane, and J.B. Johnson. 2012. Forest succession and maternity day-roost selection by Myotis septentrionalis in a mesophytic hardwood forest. International Journal of Forestry Research 2012:1-8.

Silvis, A., W.M. Ford, E.R. Britzke, and J.B. Johnson. 2014. Association, roost use, and simulated disruption of Myotis septentrionalis maternity colonies. Behavioural Processes 103:283-290.

Silvis, A., W.M. Ford, and E.R. Britzke. 2015. Effects of hierarchical roost removal on Northern Long-eared Bat (Myotis septentrionalis) maternity colonies. PLoS ONE 10:1-17.

Silvis, A., R.W. Perry, and W.M. Ford. 2016. Relationships of three species of bats impacted by white-nose syndrome to forest condition and management. General Technical Report SRS-214. US Forest Service, Southern Research Station, Asheville, NC. 48 pp.

Stepper, C., C. Straub, and H. Pretzsch. 2015. Using semi-global matching-point clouds to estimate growing stock at the plot and stand levels: Application for a broadleafdominated forest in central Europe. Canadian Journal of Forest Research 123:111-123. 
Strager, M. 2012. Landuse/landcover of West Virginia (2011). Natural Resource Analysis Center. Available online at http://wvgis.wvu.edu/data/dataset.php?ID=451. Accessed 8 February 2018.

Strausbaugh, P., and E. Core. 1978. Flora of West Virginia. Seneca Books, Morgantown, WV. 1079 pp.

Topalanchik, A.R. 1989. Soil survey of Pleasants and Tyler counties, West Virginia. US Department of Agriculture, Soil Conservation Service. Washington, DC. 127 pp.

Tovar-Pescador, J., D. Pozo-Vazquez, J.A. Ruiz-Arias, J. Batlles, G. Lopez, and J.L. Bosch. 2006. On the use of the digital elevation model to estimate the solar radiation in areas of complex topography. Meteorological Applications 13:279-287.

US Department of Agriculture. 2016. Aerial 1-m orthophotos (2016 NAIP): Natural color and color infrared. Available online at http://wvgis.wvu.edu/data/dataset.php?ID $=469$. Accessed 8 February 2018.

US Fish and Wildlife Service (USFWS). 2015. Endangered and threatened wildlife and plants; threatened-species status for the Northern Long-eared Bat with 4(d) rule; final rule and interim rule. Federal Register 80:17,974-18,033.

USFWS. 2016. Guidance on developing and implementing an Indiana Bat conservation plan. Elkins, WV. 23 pp.

US Geological Survey (USGS). 2002. Streams: National hydrography dataset (100k). Available online at http://wvgis.wvu.edu/data/dataset.php?ID=178. Accessed 8 February 2018.

USGS and West Virginia State Addressing and Mapping Board. 2003. Digital elevationmodels. Available online at http://wvgis.wvu.edu/data/dataset.php?ID=261. Accessed 8 February 2018.

Vogt, P., K. Riitters, C. Estreguil, J. Kozak, T.G. Wade, and J.D. Wickham. 2007. Mapping spatial patterns with morphological image processing. Landscape Ecology 22:171-177.

Whitaker, J.O., Jr., D.W. Sparks, and V. Brack Jr. 2004. Bats of the Indianapolis International Airport area, 1991-2011. Proceedings of the Indiana Academy of Science 113:151-161.

Whitaker, J.O., Jr., D.W. Sparks, and V. Brack Jr. 2006. Use of artificial-roost structures by bats at the Indianapolis International Airport. Environmental Management 38:28-36. 